\title{
COMPETENCE OR COMMUNICATION: FROM HR PROFESSIONALS TO EMPLOYEE PERFORMANCE VIA EMPLOYEE SATISFACTION
}

\author{
Fredson Kotamena ${ }^{1 *}$, Pierre Senjaya ${ }^{2}$, Ratna Setyowati Putri ${ }^{3}$, Carter Bing Andika ${ }^{4}$ \\ ${ }^{1,2,3,4}$ Doctoral in Research Management, Universitas Pelita Harapan \\ Jl. M.H. Thamrin Boulevard 1100, Kelapa Dua, Kec. Karawaci, Kota Tangerang, Banten 15811, Indonesia \\ *Corresponding author: kotamena@gmail.com
}

\begin{abstract}
The motivation behind this investigation was to find out the relationship between competence and communication skills of human resources professionals and employee satisfaction, as mediating variables, to improve employee performance. This study also aimed to examine the direct relationship between competence and communication skills of human resources professionals and employee performance. For data collection, a questionnaire was sent to 60 employees from the level of Section Head to Senior Manager or those directly involved in the production process and other supporting functions. The result of this study showed that the competence level of human resources professionals did not have any significant relation with employee satisfaction and employee performance. In contrast, the communication skills of human resources professionals had a significant impact on employee satisfaction and indirect correlation with employee performance; employee performance increases if employee satisfaction increases. Consequently, to be able to increase employee satisfaction, HR professionals must improve their communication skills.
\end{abstract}

Keywords: Competence of human resources professionals; communication skills of human resources professionals; employee satisfaction; employee performance.

\section{Introduction}

Employee performance refers to behavior relevant to company goals, and this behavior is under the control of every employee (Liao \& Chuang, 2004). Human Resources (HR), as a component of organizational goals, plays an essential role in helping the organization perform organizational tasks and in improving employees' performance (Alavi, Abdi, Mazuchi, Bighami, \& Heidari, 2013). In line with this role, to effectively boost organizational success, HR must be equipped with basic HR competence and must expand knowledge and experience outside the scope of HR (Cohen, 2015).

As an HR professional, with so many competencies to acquire, are there any factors influencing HR professionals to improve employee performance? Previous studies have revealed several factors that affect employee performance. Sridhar, Paul, Nath, and Kapur (2006) found that the effectiveness of communication is one of the factors increasing employee performance, especially communication that focuses on creating an excellent communicator team. The practice of HR is considered to be the primary tool to improve employee performance (Saleem \& Khurshid, 2014; Azeem \& Yasmine, 2015; Ngwenya \& Aigbavboa, 2017; Khosla, n.d.). Employees feel more safe and secure in the knowledge that HR practices are implemented appropriately within the company.
HR professionals must also be able to see changes that occur quickly and play an active role as agents of change to anticipate the effects of the occurring changes. There are times when such change can increase sales and production without additional costs (Long, Wan Ismail \& Amin, 2013; Francis \& Baum, 2018). Change is unavoidable, and the HR professional has to shield workers from the impact of the change.

The ability to implement HR practices and as agents of change requires the right competencies of $\mathrm{HR}$ professionals. Brockbank, Ulrich, Younger, and Ulrich (2012), in collaboration with research partners from all over the world, conducted studies on hundreds of HR professionals to determine the HR competencies needed. Other researchers, Lo, Macky, and Pio (2015), focused their research on more generic competencies of $\mathrm{HR}$ professionals using a universalist approach. Their findings are mostly based on HR professionals' responses. Consequently, the findings of the study about the competence of HR professionals can be biased when viewed from the perspective of other departments.

This study tried to investigate the factors that influence employee performance, both directly and through mediating variables of employee satisfaction, by focusing on the specific competence and communication skills of HR professionals from the perspective of other departments in the company. More specific research questions are formulated as follows. 
Does the competence of HR professionals affect how they communicate? Can the competencies of HR professionals improve employee satisfaction and employee performance? Do the communication skills of HR professionals affect employee satisfaction and improve employee performance? Does employee satisfaction affect employee performance?

\section{Analytical Framework}

\section{Competence of HR Professionals (C1)}

Some researchers characterize competence as a blend of viable and hypothetical information, aptitudes, conduct, and qualities used to improve execution, or being satisfactorily or very much qualified, being able to carry out a particular job. Competency is the arrangement of standards of conduct that the incumbent needs to bring to a situation to carry out his/her assignments and capacities with capability (Wodruffe, 1993).

According to Barney (1991), a company's resources or capabilities can produce sustainable competitive advantages if they have attributes, scarcity, challenging to duplicate, and irreplaceable. Interest in resource-based views and alignment theory makes Ngo, Jiang, and Loi (2014) examined the relationship between HR management competencies and company performance.

HR professionals need to replace their self-doubts with insightful information based on comprehensive worldwide information, instead of individual understanding, so that the narratives related to the HR profession have substance and importance (Ulrich, Younger, Brockbank, \& Ulrich, 2013). To provide added value, $\mathrm{HR}$ professionals must possess the knowledge, thoughts, aptitudes, and general experience applicable to organizations and competitive markets. They must be leaders in developing HR strategies so that employees and companies can build competitive advantage (Brockbank et al., 2012), while the situational perspective shows that there are HR professional competencies with more specific contexts. In other words, the importance of specific competencies depends on different roles and work situations (Lo et al., 2015).

HR professionals are considered competent if they can act according to what they say, having honesty and practical interpersonal skills, with the flexibility to build good relations with all parties. This good relationship will be an influence that contributes to business results. HR professionals can build these influences through leading-edge, smart, and openminded verbal and non-verbal communication (Brockbank et al., 2012).

The highest level of satisfaction with HR professional performance occurs when traditional HR professional abilities are used; on the contrary, the lowest level of satisfaction with HR professional performance is when HR professionals act as business partners to line executives (Lawler \& Porter, 1967). Although HR's professional role as a partner of line executives aims to include line executives in developing, approving and implementing plans regarding people and organizations (Brockbank et al., 2012), HR professionals cannot ignore the traditional core activities of their $\mathrm{HR}$ practices while working on new strategic tasks (Werner \& DeSimone, 2009). Brockbank et al. (2012), Long et al. (2013), and Lo et al. (2015) focused on HR professional competencies, which in turn, contribute to company performance. Based on the theory above, some hypotheses were formulated:

$H_{I}$ : The higher the competency level of the HR professionals, the higher the employee satisfaction.

$\mathrm{H}_{2}$ : The higher the competency level of the HR professionals, the higher the employee performance

\section{Communication Skills of HR Professional (C2)}

Communication happens through a synergy of three unique choices: Determination of information, choice of expression of this information, and a specific comprehension or misconception of the articulation and its information. Communication is a new reality, a situation sui generis, similar to life and consciousness. In this manner, communication happens just when a distinction of articulation and information is comprehended (Luhmann, 1992).

Communication becomes a significant part of an HR professional, which is as it should be. HR makes use of interchanges of ideas to strengthen organizational culture and qualities, raise employee trust, improve commitment, give information and learning, as well as to deliver an ROI to the business (Corey, n.d). In short, communication is any message expected to shape, strengthen, or change the reactions of another person or others (Stiff \& Mongeau, 2016).

To get employees to do something they are not used to doing, HR must take the initiative to communicate this with the employee. As the initial step, HR should begin with creating awareness. When employees are aware of the message being passed on, 
it will not take a long time before they understand why the changes must happen. Next, employees get the information and comprehend the message. The acknowledgment stage follows afterward, namely when employees acknowledge the aim of the message. After the employees acknowledge the message and submit sincerely or typically to the message, it is called a commitment. At the point when the employees are committed, they will do what is required by the message (Corey, n.d).

The key to business success is effective communication among all lines of the company. Reliable communication must provide, from the highest level to the lowest level workers, information about what the current industry challenges are, what is happening in the work environment, and the company's strategic objectives (Tourani \& Rast, 2012).

The professional function of human resources helps overcome crises experienced by a company. Communication during a crisis is used to provide a systematic framework for dealing with crises that occur. HR professionals as communication hubs support line managers answering essential questions from employees (Reilly, 2008; Sudhir, 2018). Employees will provide suggestions, requests, and complaints through HR professionals. The ability to respond is not interpreted as an HR professional's assertiveness, but, instead, the ability to express feelings and emotions. Being responsive as a predictor of employee satisfaction reflects more in the sensitivity to communicate with others by recognizing the desires and needs of others (Elshaer, 2013). On top of that, in order to influence employees' perceptions and practices, the HRM strategy must be conveyed well throughout the organization. logical:

Therefore, the following hypotheses appear

$H_{3}$ : The higher the competency level of the HR professionals, the more effective the communication skills of the HR professionals.

$H_{4}$ : The higher the communication skills of the HR professionals, the higher the employee satisfaction.

$H_{5}$ : The higher the communication skills of the HR professional, the higher the employee performance.

\section{Employee Satisfaction (E1)}

The word "satisfy" has a distinctive meaning to many employees. Outside of a particular setting, however, the word "satisfy" is obscure. Dictionary characterizes "satisfaction" as a delight of a craving, regularly one related to happiness and solace. Many researchers have defined the word "employee satisfaction." Lashbrook identified two principal contexts for satisfaction: personal satisfaction and group satisfaction. In this particular study, we would follow Lashbrook's definition. We believe employee satisfaction is simply the personal satisfaction with himself or herself at work, his/her fulfillment with the job itself, his /her fulfillment with his/her associations with colleagues, and his/her fulfillment with how he/ she is led (Lashbrook, 1997).

In 1924-1933, Elton Mayo, who directed Hawthorne study, concentrated his research on work fulfillment. He intended to find the effects of various conditions on employee efficiency. The Hawthorne impact showed that new changes in work conditions unexpectedly increased profits. Later on, it was discovered that this increase was not as a result of the new conditions, but because individuals modify an aspect of their behavior in response to their awareness of being observed. This discovering gives strong verification that people work for aspiration other than pay, which opens the route for analysts to inquire about different aspects of job satisfaction (Kaur, 2012).

Employee satisfaction is not only a result of positive assessments of employee work experience, but also an effect of HR practices such as performance appraisal processes, wage structures, training and career development, and work-life balance (Shmailan, 2016; Aldakhil, Wu, Rezaei, \& Cobanoglu, 2017). Furthermore, Chi and Gursoy (2009) and Coggburn and Bradbury (2014) examine the connection between employee satisfaction and customer satisfaction directly on the company's financial performance. Their study found that there was no significant direct effect on employee satisfaction with company financial performance. In the end, stability, enthusiasm, and the quality of their work are related to the level of employee satisfaction; this includes the company's long-term opportunities. This thought was upheld by $\mathrm{Gu}$, Siu and Yan, stating that worker satisfaction has a strong relationship with their performance (Gu \& Siu, 2009; Yan, 2019). Therefore, the following hypotheses were formulated:

$H_{6}$ : The higher the level of employee satisfaction, the higher the employee performance.

Thus, the relationship between each of these variables is discussed and hypothesized. The research model was conceptually made according to Figure 1. 


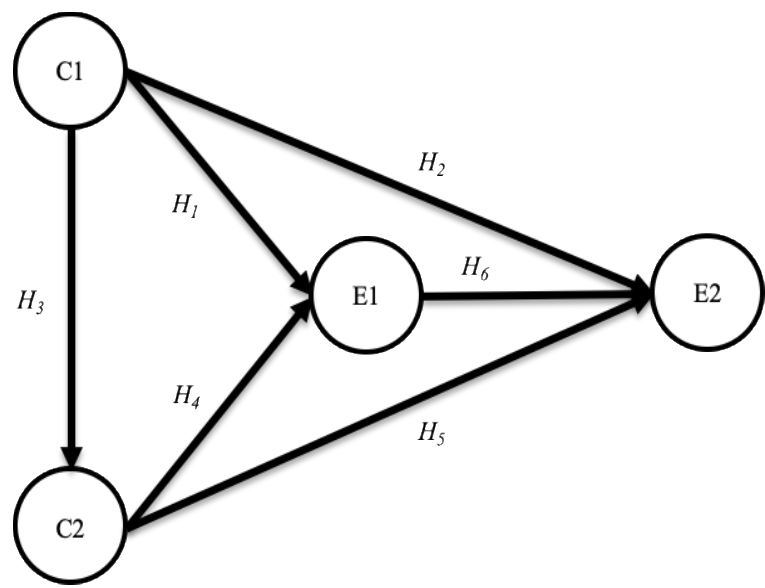

Figure 1. Conceptual model of the relationship between the competence of hr professionals, communication skills of hr professionals, employee satisfaction, and employee performance

\section{Research Method}

\section{Sample Selection Procedure and Data Collection}

As we are all aware, data collection is critical in research since the information will be analyzed to understand the analytical framework better. This investigation intentionally used a purposive sampling technique because of the nature of the respondents. The samples were chosen from people or groups of people that were capable and well-informed of the subject of the research (Etikan, Musa, \& Alkassim, 2016). These carefully chosen samples had a relatively thorough understanding of the domain about which they spoke. Carefully chosen samples increase internal validity. The understanding of the results is restricted to the population under examination in the purposive sampling. In order to increase its validity as a common reason for a hypothesis, this study must be rehashed in different populations (Tongco, 2007).

Keeping those conditions in mind, the researcher collected data using a questionnaire distributed to a total population of 60 employees from the level of Section Heads to Senior Managers working in functions directly involved in the production process, as well as other supporting functions. Sixty employees were selected as they held the knowledge, expertise, and position within the organization to give a proper perspective. Questionnaires were distributed online, and anonymous responses were submitted to ensure more freedom of opinion. The research aimed to understand and measure the competence and communication of the HR department from the perspective of the production department as well as other supporting functions. Therefore, section Heads to
Senior Managers who were responsible for carrying out HR functions in the company did not participate in filling out the questionnaires.

The responses received in this study were $78.3 \%$, or as many as 47 employees filled out and returned the questionnaires from the total population of 60 employees. Then, these questionnaires were processed using Smart PLS to display its statistical data analysis. The software has gained popularity since it has a friendly user interface and sophisticated reporting features. PLS-SEM is a good alternative for this study because of its small sample size, and the correct model specification was still unknown (Wong, 2013).

As shown in the Appendix, the questionnaire was developed based on several literature references and with 1-5 measurement scale. In this study, employee performance is the primary variable, and it refers to behavior relevant to company goals (Liao \& Chuang, 2004).

\section{Methods}

There are two sub-models when we utilize the Structural Equation Model (SEM). The first model is the inner or structural model, which determines the connection between the independent and dependent latent variables. Next, the second model, the outer or measurement model, determines more of the connection between the latent variables and their observed indicators (Ghozali \& Latan, 2015).

Multi-item, instead of single-item, was used to measure the latent construct because of the sample size (60). The research initially included a total of 60 indicators, with fifteen indicators for each variable. In this model, there was one independent variable, namely Competence of HR Professionals (C1), and two mediating variables, namely Communication skills of HR Professionals (C2) and Employee Satisfaction (E1). A dependent variable, Employee Performance (E2), was also included. Firstly, using Smart PLS, a standard step Partial Least Square (PLS) algorithm was run to help researchers obtain the value of latent variables as predicted to test the nature of research instruments. Factor examination, Cronbach Alpha, unwavering quality, item correlation, and average variance extracted were actualized. Factors examination was conducted to evaluate the underlying relationships between/among items and to reduce the arrangement of elements. In this manner, all loading factors with an estimation of 0.644 to 0.887 were considered more prominent than the 0.60 cut-offs and were statistically significant (Ghozali \& Latan, 2015). 
After the process, the number of indicators was reduced to 16 indicators. Four indicators were assigned to each of the four variables. The indicators were developed to assess how HR deal with employees, how well HR communicate information, employee work-life balance, and how the company values employee performance as well as the perceived employee performance as shown in the Appendix. The research questionnaires consisted of four statements for each variable measured. A five-point Likert scale was used, with $1=$ strongly disagree, and $5=$ strongly agree (Krosnick, 2018).

\section{Result and Discussion}

This study used Smart PLS to validate and test the reliability of the instruments used and perform data processing and statistical analysis. After the validity test, the outer loading value of each indicator was examined, and only substantial indicators were included. According to Ghozali and Latan (2015), the underlying exploration loading factor between $0.5-0.6$ is adequate. However, in this investigation, the cut-off of the outer loading factor was from 0.6. Consequently, all indicators with the loading factor below 0.6 were excluded. Those with the loading factors from 0.644 to 0.887 were considered more valid. The higher the value of the loading factors, the better the ability of the question to measure what it is intended, regardless of the simplicity or complexity of the question. The validity of the indicators is substantial in determining the validity of the research findings.

Table 1

Validation Results

\begin{tabular}{ccccc}
\hline Variable & $\begin{array}{c}\text { Cronbach's } \\
\text { Alpha }\end{array}$ & rho_A & $\begin{array}{c}\text { Composite } \\
\text { Reliability }\end{array}$ & $\begin{array}{c}\text { Average } \\
\text { Variance } \\
\text { Extracted } \\
\text { (AVE) }\end{array}$ \\
\hline C1 & 0.834 & 0.840 & 0.889 & 0.667 \\
C2 & 0.873 & 0.880 & 0.913 & 0.724 \\
E1 & 0.805 & 0.820 & 0.872 & 0.631 \\
E2 & 0.734 & 0.750 & 0.834 & 0.559 \\
\hline
\end{tabular}

Table 1 explains the results of the validation that the data obtained meets the requirements and is declared eligible for the research because the Cronbach's Alpha coefficient is above 0.70. At the same time, the Composite Reliability is above 0.70 , while the Average Variance Extracted is above 0.50 .

Table 2 shows figures from 1.000-2.177, smaller than 5.000, meaning that this data is free from multicollinearity. To further test existing data, SEM is more appropriate to use for investigating the relationship.
Table 2

Collinearity Statistics (VIF)

\begin{tabular}{ccccc}
\hline & $\mathrm{C} 1$ & $\mathrm{C} 2$ & $\mathrm{E} 1$ & $\mathrm{E} 2$ \\
\hline $\mathrm{C} 1$ & & 1.000 & 1.708 & 1.711 \\
$\mathrm{C} 2$ & & & 1.708 & 2.177 \\
$\mathrm{E} 1$ & & & & 1.517 \\
$\mathrm{E} 2$ & & & & \\
\hline
\end{tabular}

Table 3

$R$-square

\begin{tabular}{ccr}
\hline & $R$-Square & \multicolumn{1}{r}{$\begin{array}{c}\text {-Squared } \\
\text { Adjusted }\end{array}$} \\
\hline C2 & 0.414 & 0.401 \\
E1 & 0.341 & 0.311 \\
E2 & 0.443 & 0.404 \\
\hline
\end{tabular}

$R$-square shows that the Competence of HR professionals has an influence on HR professional communication skills by $41.4 \%$. The competence of HR professionals and the communication skills of HR professionals has a $34.1 \%$ influence on employee satisfaction. On the other hand, the competence of HR professionals, communication skills of HR professionals, and employee satisfaction have an influence on employee performance at $44.3 \%$.

Table 4

Total Indirect Effects

\begin{tabular}{llllll}
\hline Relationship & $\begin{array}{l}\text { Original } \\
\text { Sample (0) }\end{array}$ & $\begin{array}{l}\text { Sample } \\
\text { Mean (M) }\end{array}$ & $\begin{array}{c}\text { Std.Deviation } \\
(\text { STDEV) }\end{array}$ & $\begin{array}{c}\text { t-statistic } \\
(\text { O/STDEV })\end{array}$ & $p$-values \\
\hline $\mathrm{C} 1 \rightarrow \mathrm{E} 1$ & 0.358 & 0.340 & 0.156 & 2.299 & 0.022 \\
$\mathrm{C} 1 \rightarrow \mathrm{E} 2$ & 0.243 & 0.275 & 0.178 & 1.363 & 0.173 \\
$\mathrm{C} 1 \rightarrow \mathrm{C2}$ & & & & & \\
$\mathrm{C} 2 \rightarrow \mathrm{E} 1$ & & & & & \\
$\mathrm{C} 2 \rightarrow \mathrm{E} 2$ & 0.363 & 0.332 & 0.150 & 2.424 & 0.016 \\
$\mathrm{E} 1 \rightarrow \mathrm{E} 2$ & & & & & \\
\hline
\end{tabular}

The indirect effect of competence of HR professionals on employee satisfaction through HR communication skills is $35.8 \%$. In contrast, the indirect effect of competence of HR professionals on employee performance through employee satisfaction is $24.3 \%$. The indirect effect of the communication skills of HR professionals through employee satisfaction is $36.3 \%$.

Table 4 explains that the relationship between the competence of HR professional and employee satisfaction, through HR professional communication skills, has a significant effect, because the $p$-values < 0.05 . The competence of HR professionals does not have a significant effect on employee performance through employee satisfaction with $p$-values $=0.173$. Communication skills of HR professionals itself has a significant influence on employee performance through employee satisfaction with $p$-values $=0.016$. 
Table 5

Specific Indirect Effects

\begin{tabular}{|c|c|c|c|c|c|}
\hline Relationship & $\begin{array}{l}\text { Original } \\
\text { Sample (0) } \\
\end{array}$ & $\begin{array}{l}\text { Sample } \\
\text { Mean (M) }\end{array}$ & $\begin{array}{l}\text { Std. Deviation } \\
\text { (STDEV) }\end{array}$ & $\begin{array}{l}t \text { - statistic } \\
(\text { O/ STDEV) }\end{array}$ & $p$-values \\
\hline $\mathrm{Cl} \rightarrow \mathrm{CL}+\mathrm{El}$ & 0.358 & 0.340 & 0.156 & 2.299 & 0.022 \\
\hline $\mathrm{Cl} \rightarrow \mathrm{C} 2 \rightarrow \mathrm{E} 2$ & -0.019 & 0.010 & 0.135 & 0.138 & 0.890 \\
\hline Cl $\rightarrow E 1+E 2$ & 0.027 & 0.043 & 0.142 & 0.191 & 0.849 \\
\hline CLIE1 $\rightarrow E 2$ & 0.363 & 0.332 & 0.150 & 2.424 & 0.016 \\
\hline CIACHEHELE) & 0.234 & 0.221 & 0.114 & 2.058 & 0.040 \\
\hline
\end{tabular}

Table 5 explains the specific indirect effects of the relationships between variables. The relationship between the competence of HR professionals indirectly has a strong influence on employee satisfaction through the communication skills of HR professionals with $p$-values $=0.022$. The competence of HR professionals has no significant effect on employee performance through the communication skills of HR professionals with $p$-values $=0.890$.

Communication skills of HR Professionals have a significant indirect effect on employee performance through employee satisfaction, $p$-values $=0.016$. In contrast, the specific indirect relationship of the competence of $\mathrm{HR}$ professionals, communication skills of HR professionals, and employee satisfaction have a significant influence on employee performance, $p$-values $=0.040$.

\section{Table 6}

Path Coefficients and Hypothesis Testing

\begin{tabular}{ccccccc}
\hline Hypothesis & Relationship & $\begin{array}{c}\text { Original } \\
\text { Sample (0) }\end{array}$ & $\begin{array}{c}\text { Sample } \\
\text { Mean (M) }\end{array}$ & $\begin{array}{c}\text { Std. Deviation } \\
\text { (STDEV) }\end{array}$ & $\begin{array}{c}\text { t-statistic } \\
\text { (O/STDEV) }\end{array}$ & p-values \\
\hline H1 & C1 $\rightarrow$ E1 & 0.042 & 0.068 & 0.218 & 0.191 & 0.849 \\
H2 & C1 $\rightarrow$ E2 & 0.067 & 0.053 & 0.181 & 0.371 & 0.711 \\
H3 & C1 $\rightarrow$ C2 & 0.644 & 0.653 & 0.094 & 6.880 & 0.000 \\
H4 & C2 $\rightarrow$ E1 & 0.556 & 0.512 & 0.203 & 2.740 & 0.006 \\
H5 & C2 $\rightarrow$ E2 & -0.029 & 0.012 & 0.199 & 0.146 & 0.884 \\
H6 & E1 $\rightarrow$ E2 & 0.654 & 0.645 & 0.120 & 5.458 & 0.000 \\
\hline
\end{tabular}

\section{The higher the competency level of $H R$ professionals (C1), the higher the employee satisfaction (E1)}

Table 6 explains that the competence of HR professionals does not have a strong influence on employee satisfaction $(b=0.042, p$-values 0.849 > 0.05 ). With the number of samples as many as 47 employees and three independent variables, the value of $t$-table is 2.0154, which shows that the relationship between $\mathrm{C} 1 \rightarrow \mathrm{E} 1$ having $t$-value $=0.191$ is not significant.

The finding aligns with the statement of Brockbank et al. (2012) that HR professionals are considered competent if they can act according to what they say, such as having honesty and practical interpersonal skills, and with the flexibility to build good relations with all parties. There is a common misinterpretation between competency and job roles (Wodruffe, 1993). Competency is not quite the same as parts of the job description. They are what an individual brings to the activity.

How is the employee satisfied with the HR function? According to Lawler and Porter (1967), the highest level of satisfaction with the performance of HR professionals occurs when they use their traditional HR professional abilities. Moreover, the lowest level of satisfaction with HR professional performance is when HR professsionals act as business partners to line executives. In contrast, organizations endeavor to make their HR highly capable of financial savvy-ness as it is vital for organizations. With the changing job descripttion of HR experts and far-reaching moves to revert HR obligations to line executives (Francis \& Baum, 2018), more and more HR professionals neglect their traditional capabilities. That proposition confirms the finding of this study.

\section{The higher the competency level of $H R$ professionals (C1), the higher the employee performance (E2)}

First and foremost, an HR professional must have specialized HR knowledge. In other words, this is the expense of the calling. A comprehension and capacity to adequately rehearse employee and work relations, remuneration and benefits, training and promotion of the employee, workforce and business arrangement, chance administration, and critical administration, coupled with some understanding of HR innovation, are all essential to accomplish the job in HR. Likewise, HR experts should have the option to apply the fundamental standards and practices of HR to improve the performance of their associates (Cohen, 2015). Improving efficiency and employee performance is the fundamental of adequate actualization of HRM practices, which in turn, resulting in the organization's competitiveness.

Some investigations reported that contented and satisfied employees perform better in their work. It is said that an employee with a high grit executes their work better. Next, the increasing performance correlates with the employee's performance and promotion (Ngwenya \& Aigbavboa, 2017). Although HR considers employees as significant elements in achieving the organization's goals and to maintain its competitive edge, numerous leaders do not consider that $\mathrm{HR}$ is a noteworthy component affecting the business performance. Hardly any investigations have paid attention to the immediate impact of $\mathrm{HR}$ practices and employee performance (Saleem \& Khurshid, 2014). 
Based on the data analysis of this investigation, as shown in Table 6, we can conclude that the competence of HR professionals does not have any strong influence on employee performance with a positive direction $(b=0.067, p$-values $0.711>0.05)$. The relationship between $\mathrm{C} 1 \rightarrow \mathrm{E} 2$ is not significant, as shown in Table 6, with $t$-value $=0.371$.

\section{The Higher the Competence Level of HR Professionals (C1), the More Effective the Communication Skills of HR Professionals (C2)}

The result analysis shows that the competence of HR professionals has a strong influence on HR professionals' communication skills $(b=0.644, p$ values $0.000<0.05$ ), with $t$-value $=6.880$, showing a significant relationship between the two. Communication is the product of a synergy of three unique choices, namely determination of information, choice of expression for this information, and a specific comprehension or misconception of the articulation and its information (Luhmann, 1992).

As stated by Brockbank et al. (2012), HR professionals are considered competent if they can act according to what they say. That competence includes having honesty and practical interpersonal skills, as well as the flexibility to build good relations with all parties. HR professionals can build these influences through leading-edge, smart, and open-minded verbal and non-verbal communication (Brockbank et al., 2012). HR specialists need to concentrate more on teaming up with top management and line executives in technical definition and execution rather than on their operational practices (Lo et al., 2015).

HR experts need to manage related documents and correspondence to meet the objectives of the organization. Such management is crucial for critical consideration, gaining understanding from the starting point, and overseeing challenges throughout a project. In this way, the persons in charge and their job descriptions are clear, and the cost of the project can be monitored (Corey, n.d). For these objectives, HR professionals, in addition to their knowledge of $\mathrm{HR}$, must possess the capability in management as well. Thus, improving HR capability, in the end, will increase communication skills.

\section{The Higher the Communication Skills of HR Professionals (C2), the Higher Employee Satisfaction (E1)}

The communication skills of HR professionnals have a strong influence on employee satisfaction $(b=$
$0.556, p$-values $0.006<0.05)$. With $t$-value $2.740>t$ table 2.0154 , this study proved that the communication skills of HR professionals have a positive relationship with employee satisfaction. Communication assumes a critical role in building and keeping up employees' trust, which becomes the most significant component for employees to voice their concerns or aspirations. Employees should be allowed to offer the board their inputs and proposals, or voice their interests or concerns, trusting that their ideas will be listened to and where appropriate acted upon. Open and honest communication will build trust. Communication is one of the best five commitment drivers besides job vacancy, performance, organization reputation, and pay.

Trust and commitment can be positively or adversely affected by communication. Communication becomes a useful asset to HR experts to build personal satisfaction that will prompt the accomplishment of important goals (Corey, n.d). Similar studies indicate that open and supportive communication among employees has been considered as a source of job satisfaction (Klauss \& Bass, 1982; King, Lahiff, \& Hatfield, 1988; Trombetta \& Rogers, 1988; Ducharme \& Martin, 2000). Hence, management should create emotionally supportive networks in the critical structure so that employees can convey their needs and concerns. Proper communication is viewed as a fundamental component of the organization that should bring employees to some understanding of challenges in the industry, what is going on in the working environment, and the organizational objectives. Above all, with proper communication, an organization will run successfully and will be able to keep their key-asset personnel.

\section{The Higher the Communication Skills of HR Professionals (C2), the Higher the Employee Performance (E2)}

The communication skills of HR professionnals do not directly have a strong influence on employee performance with a negative relationship $(b=-0.029$, $p$-values $0.884>0.05$ ), and $t$-value 0.146 . The data shows a weak relationship between the communication of HR professionals and employee performance. The findings weakly support what Sridhar et al. (2006) stated about the effectiveness of communication as one of the factors increasing employee performance, especially communication that focuses on creating an excellent communicator team.

As openness and honesty become one of the most significant factors to improve employee satisfaction, it 
is not related directly to employee performance. On the other hand, a negative correlation, as shown in employee dissatisfaction, occurs with too much openness and honesty during a communication related to individuals' performance.

Pincus (1986) and Madlock (2008) revealed the same realities about communication by a superior, in which the atmosphere of the communication and personal criticism is perceived as related to job performance. Although a relationship with the subordinate is established, communication with top management is considerably identified with work execution and, to a lesser degree, with job performance. The study also confirmed that, in communication with top management, the more senior his/her position within an organization, the higher the defense mechanism of subordinates when they are criticized for underperformance.

The present investigation supports hypothetical information concerning how the executive's assertion and reception influences performance, with suggestions for practice. In particular, it reveals that management communication influences performance mostly because it flags up that the organization thinks about the welfare and commitment quality of its workers (Neves \& Eisenberger, 2012).

\section{The Higher the Level of Employee Satisfaction (E1), the Higher the Employee Performance (E2)}

Employee satisfaction has a very significant influence on employee performance in a positive direction $(b=0.654, p$-values $0.000<0.05)$, with $t$ value $=5.458$, confirming the significant relationship between the two.

In the service industry, many studies recommend that, for service employees, employee satisfaction continues to play an essential part in their work environment. Studies demonstrated that job satisfaction impacts the perspective and the way the service is performed that, as a result, influences the service quality experienced by the client (Gu \& Siu, 2009).

Many research confirms that unsatisfied employees do not perform well and become a hindrance to the progress of their organization, whereas satisfied employees improve and add to the general achievement of their organization. Having satisfied employees with high performance and are in the correct employments helps cultivate commitment. Furthermore, engaged employees need healthy communication with their bosses, work that has significance for them, and excites them (Shmailan, 2016). Many researchers have investigated and discovered similar conclusions about the correlation between workers' commitment and how the workers do their job. The more passionate the laborers are, the better the outcomes they accomplish for the organization (Vorina, Simonič, \& Vlasova, 2017). In short, job satisfaction is positively and significantly related to employee performance (Siengthai \& Pila-Ngarm, 2016).

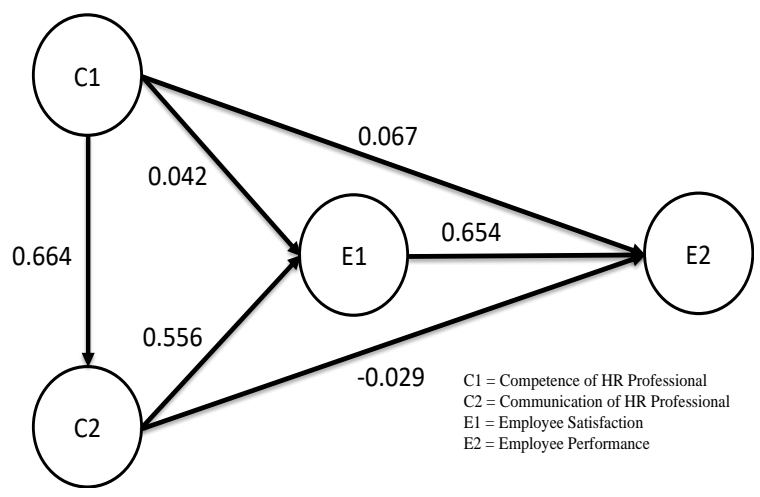

Figure 2. Summary of the relationship between the competence of $\mathbf{h r}$ professionals, communication skills of $\mathrm{hr}$ professionals, employee satisfaction and employee performance

Table 7

Hypothesis Test Results

\begin{tabular}{|c|c|c|}
\hline & Hypothesis Proposition & Result \\
\hline$\overline{H_{1}}$ & $\begin{array}{l}\text { The higher the competency } \\
\text { level of the HR professionals, } \\
\text { the higher the employee } \\
\text { satisfaction }\end{array}$ & Rejected \\
\hline $\mathrm{H}_{2}$ & $\begin{array}{l}\text { The higher the competency } \\
\text { level of the HR professionals, } \\
\text { the higher the employee } \\
\text { performance }\end{array}$ & Rejected \\
\hline$H_{3}$ & $\begin{array}{l}\text { The higher the competence } \\
\text { level of HR professionals, the } \\
\text { more effective the } \\
\text { communication skills of HR } \\
\text { professionals }\end{array}$ & Accepted \\
\hline$H_{4}$ & $\begin{array}{l}\text { The higher the communication } \\
\text { skills of the HR professionals, } \\
\text { the higher the employee } \\
\text { satisfaction }\end{array}$ & Accepted \\
\hline$H_{5}$ & $\begin{array}{l}\text { The higher the communication } \\
\text { skills of the HR professionals, } \\
\text { the higher the employee } \\
\text { performance. }\end{array}$ & Rejected \\
\hline$H_{6}$ & $\begin{array}{l}\text { The higher the level of } \\
\text { employee satisfaction, the } \\
\text { higher the employee } \\
\text { performance }\end{array}$ & Accepted \\
\hline
\end{tabular}




\section{Contribution and Future Studies}

Researchers found that there was no significant direct impact on employee satisfaction with the company's financial performance (Chi \& Gursoy, 2009). Does employees' performance affect the company's performance? This issue is something to investigate further in the future.

This study found that employee satisfaction is influenced more by how HR professionals carried out communication rather than by the competence of HR professionals itself, whereas the proper competency level of HR Professionals will enhance HR professionals' communication skills. Hence, if the indirect relationship improves employee performance, an HR professional must increase his/her competence. In contrast, Lawler and Porter (1967) stated that the highest level of satisfaction with HR professionals' performance occurs when they use the traditional capabilities of HR practices, while the lowest level of employee satisfaction with HR professionals' performance is when HR professionals act as business partners. Further research is needed to clarify this because it is contradictory to what Brockbank et al. (2012) and Lai, Saridakis, and Johnstone (2017) found in their research. The latter reseachers claimed that HR professionals in high-performance companies have a role as credible inspirators; they must be able to become mediator and create good relationships with key decision-makers in order to make any influence contributing to company performance.

The next question is, what determines the level of employee performance that contributes to higher company performance. For sure, it is a complex issue with many factors influencing it. Some can be measured, and others cannot be measured; some are internal, and some are external (Child, 1975). This issue is a topic that can be investigated further in the future.

\section{Conclusion}

Through this research, HR professionals can focus on developing their abilities towards a more strategic direction towards the company's progress, specifically developing an understanding of the business in the industry. Furthermore, to improve employee performance, HR professionals need to sharpen their communication. Lines of communication, both formally and informally, must be established, and the contents of communication must be aligned more to the progress of the company.

The significant correlation path between the competence of HR professionals and the communication skills of HR professionals, then employee satisfaction and employee performance, could be influenced by other variables that were not examined here. For this reason, rather than on the conventional HR practice which has a narrow focus on things such as personnel management, HR professionals can focus on improving employee performance through employee satisfaction with information provided that is relevant to the situation and condition of the company, strategic plans, achievement targets, and ways to achieve these goals.

Nevertheless, the processes and procedures used by companies to manage recruitment, training, and development (Fan \& Wang, 2015) can still be implemented without excessive emphasis on increasing employee satisfaction. The main focus is not what increases employee performance, but that communication plays a vital role in increasing employee satisfaction. Men (2014) stated that the key to regular communication emphasizes listening to others, openness in delivery, feedback, participation, and good relations with the parties to whom we convey the information. Thus, to conclude, an improvement in how to communicate with empathy and content mastery are two among other competencies HR professionals need to master.

\section{Appendix}

Measurement of variables

\footnotetext{
Indicator

Competence of HR Professionals (C1)

1. HR gives timely responses.

2. HR has the capability of recruitment and selection.

3. HR can connect day-to-day circumstances in the company with the company policies.

4. The HR department can deal with employees in an informal setting.

Communication of HR Professionals (C2)

1. Information received from the HR department is clear.

2. HR works hard to improve communication with all employees.

3. In general, I am satisfied with the communication carried out by HR.

4. The HR department can communicate in writing well.

Employee Satisfaction (E1)

1. I take pride in working in this company.

2. I maintain a good work-life balance.

3. I like the company culture.

4. The company provides adequate opportunities for promotion.
} 
Employee Performance (E2)

1. In this company, people are valued based on their performance.

2. My company provides high-quality services.

3. My department produces high-quality products.

4. My department provides high-quality services.

\section{References}

Alavi, H. R., Abdi, F., Mazuchi, M., Bighami, M. K., \& Heidari, A. (2013). An investigation on effective factors influencing employee performance: A case study. Management Science Letters, 3(6), 1789-1794. https://doi.org/10.5267/ j.msl.2013.05.002

Aldakhil, M. A. A. M., Wu, C., Rezaei, S., \& Cobanoglu, C. (2017). The structural relationship between tqm, employee satisfaction and hotel performance. International Journal of Contemporary Hospitality Management, 29 (4), 12561278. https://doi.org/10.1108/IJC HM-11-20150659

Azeem, M. F., \& Yasmine, R. (2015). Role of human resource practices on employee performance. Science International (Lahore), 27(6), 64036412.

Barney, J. (1991). Firm resources and sustained competitive advantage. Journal of Management, 17(1), 99-120. https://doi.org/10.1177 \%2F0149 20639101700108

Brockbank, W., Ulrich, D., Younger, J., \& Ulrich, M. (2012). Recent study shows impact of $\mathrm{hr}$ competencies on business performance. Employment Relations Today, 39(1), 1-7. doi: 10.1002/ ert. 21348

Chi, C. G., \& Gursoy, D. (2009). Employee satisfaction, customer satisfaction, and financial performance: An empirical examination. International Journal of Hospitality Management, 28(2), 245-253. https://doi.org/10.101 6/j.jijhm. 2008.08.003

Child, J. (1975). Managerial and organizational factors associated with company performance-Part II. A contingency analysis. Journal of Management Studies, 12(1-2), 12-27. Retrieved from https://doi.org/10.1111/j.146 76486.1975.tb00884.x

Coggburn, J. D., Jr., R. P. B., \& Bradbury, M. D. (2014). Employee job satisfaction and organizational performance: The role of conflict management. International Journal of Organization Theory \& Behavior Employee, 17 (04), 498-530.
Cohen, D. J. (2015). HR past, present and future: A call for consistent practices and a focus on competencies. Human Resource Management Review, 25(2), 205-215. https://doi.org /10.1016/ j.hrmr.2015.01.006

Corey, D. (2016). Effective hr communication: A framework for communicating $\mathrm{hr}$ programmes with impact. $1^{\text {st }}$ Edition. London, UK: Kogan Page Limited.

Ducharme, L. J., \& Martin, J. K. (2000). Unrewarding work, coworker support, and job satisfaction: A test of the buffering hypothesis. Work and Occupations, 27(2), 223-243. https://psycnet.apa.org/ doi/10.1177/0730888400027002005

Elshaer, I. A. (2013). The relationship between managers' communication skills and employees' job satisfaction. Journal of Association of Arab Universities for Tourism and Hospitality, 2(Special Issue), 137-147.

Etikan, I., Musa, S. A., \& Alkassim, R. S. (2016). Comparison of convenience sampling and purposive sampling. American Journal of Theoretical and Applied Statistics, 5(1), 1-4. https://doi.org/10.11648/j.ajtas.20160501.11

Fan, B., \& Wang, H. (2015). Evaluation of traditional and strategic human resource management. 2015 International Conference on Engineering Management, Engineering Education and Information Technology. Advances in Computer Science Research (pp. 242-245). https://doi.org/ 10.2991/emeeit-15.2015.49

Francis, H., \& Baum, T. (2018). HR transformation within the hotel industry: Building capacity for change. Worldwide Hospitality and Tourism Themes, 10(1), 86-100. https://doi. org/10.1108/ WHATT-102017-0064

Ghozali, I., \& Latan, H. (2015). Partial least squares konsep, teknik dan aplikasi menggunakan program SmartPLS 3.0. $2^{\text {nd }}$ Edition. Semarang: Badan Penerbit UNDIP.

Gu, Z., \& Siu, R. C. S. (2009). Drivers of job satisfaction as related to work performance in Macao casino hotels: An investigation based on employee survey. International Journal of Contemporary Hospitality Management, 21(5), 561-578. https://doi.org/10.1108/09596110910 967809

Kaur, R. (2012). The role of factors on job satisfaction of employees - An empirical study. IOSR Journal of Business and Management, 2(4), 49-52. https://doi.org/10.9790/487x-02 44952

Khosla, D. (n.d.). Emerging hr practices and its impact on employees' satisfaction in teaching in 
Haryana. Retrieved from https://ww w.academia.edu/34214720/Emerging_HR_Practices_an d_its_impact_on_Employees_Satisfaction_in_T eaching_in_Haryana. 1-12.

King, W. C., Lahiff, J. M., \& Hatfield, J. D. (1988). Communication and Job Satisfaction. Communication Research Reports, 5 (1), 36-43. https://doi. org/10.1080/08824098809359798

Klauss, R., \& Bass, B. M. (1982). Interpersonal communication in organizations. NewYork: Academic Press.

Krosnick, J. A. (2018) Questionnaire design. In D. Vannette, \& J. Krosnick (Eds), The Palgrave Handbook of Survey Research (pp 439-455). Switzerland: Palgrave Macmillan, Cham. https://doi.org/10.1007/978-3-319-54 395-6_53

Lai, Y., Saridakis, G., \& Johnstone, S. (2017). Human resource practices, employee attitudes and small firm performance. International Small Business Journal: Researching Entrepreneurship, 35(4), 470-494. https://doi.org/10.1177/02662426166 37415

Lashbrook, W. (1997). Business performance, employee satisfaction, and leadership practices. Performance Improvement, 36(5), 29-33. https://doi.org/10.1002/pfi.4140360508

Lawler, E. E., \& Porter, L. W. (1967). The effect of performance on job satisfaction. Industrial Relations: A Journal of Economy and Society, 7(1), 20-28. https://doi.org/10.1111/j. 1468232X.1967.tb01060.x

Liao, H., \& Chuang, A. (2004). A multilevel investigation of factors influencing employee service performance and customer outcomes. Academy of Management Journal, 47(1), 41-58. https://doi.org/10.2307/20159559

Lo, K., Macky, K., \& Pio, E. (2015). The hr competency requirements for strategic and functional $\mathrm{hr}$ practitioners. International Journal of Human Resource Management, 26(18), 2308-2328. https://doi.org/10.1080/0958519 2.2015.1021827

Long, C. S., Wan Ismail, W. K., \& Amin, S. M. (2013). The role of change agent as mediator in the relationship between HR competencies and organizational performance. International Journal of Human Resource Management, 24(10), 2019-2033. https://doi.org/10.1080/09585192. 2012.725080.

Luhmann, N. (1992). What is communication? Communication Theory, 2(3), 251-259. https://doi. org/10.1111/j.14682885.1992.tb00042.x.

Madlock, P. E. (2008). The link between leadership style, communicator competence, and employee satisfaction. Journal of Business Communication,
45(1), 61-78. https://doi.org/10.1177/00219436 07309351

Men, L. R. (2014). Strategic Internal Communication: Transformational Leadership, Communication Channels, and Employee Satisfaction. Management Communication Quarterly, 28(2), 264-284. https://doi.org/10.117 7/0893318914524536

Neves, P., \& Eisenberger, R. (2012). Management communication and employee performance: The contribution of perceived organizational support. Human Performance, 25(5), 452-464. https://doi.org/10.1080/08959285.2012. 721834

Ngo, H., Jiang, C.-Y., \& Loi, R. (2014). Linking hrm competency to firm performance: An empirical investigation of Chinese firms. Personnel Review, 43, 898-914. https://doi.org/10.1108/ PR-05-2013-0086

Ngwenya, L., \& Aigbavboa, C. (2017). Improvement of productivity and employee performance through an efficient human resource management practices. In J. I. Kantola, T. Barath, S. Nazir, \& T. Andre (Eds), Advances in Human Factors, Business Management, Training and Education. Part of the Advances in Intelligent Systems and Computing book series (AISC, volume 498) (pp. 727-737). Switzerland: Springer, Cham. https://doi.org/10.1007/978-3319-420707_67

Pincus, J. D. (1986). Communication satisfaction, job satisfaction, and job performance. Human Communication Research, 12(3), 395-419. https://doi.org/10.1111/j.1468-2958.19 86.tb000 84.x

Reilly, A. H. (2008). The role of human resource development competencies in facilitating effective crisis communication. Advances in Developing Human Resources, 10(3), 331-351. https://doi.org/10.1177/1523422307313659

Saleem, I., \& Khurshid, A. (2014). Do human resource practices affect employee performance? Pakistan Business Review, 15(4), 669-688. Retrieved from http://www.iobm.edu.pk/PBR/PBR_14 01_V15N4/PBR_V15N4.pdf\#page=131

Shmailan, A. S. Bin. (2016). The relationship between job satisfaction, job performance and employee engagement: An explorative study. Issues in Business Management and Economics, 4(1), 18. https://doi.org/10.15739/IB ME.16.001

Siengthai, S., \& Pila-Ngarm, P. (2016). The interaction effect of job redesign and job satisfaction on employee performance. Evidence-Based HRM, 4(2), 162-180. https://doi.org/ 10.1108/EBHRM $-01-2015-0001$ 
Sridhar, V., Paul, R., Nath, D., \& Kapur, K. (2006). Analyzing factors that affect performance of global virtual teams. Retrieved from https://pdfs. semanticscholar.org/4ae3/df4b3e95d576413 c6574994d7495d0fed0a4.pdf

Stiff, J., \& Mongeau, P. (2016). Persuasive communication. Third Edition. UK: Guilford Publications.

Sudhir, S. (2018). Rumors in organizational communication: A nightmare for $\mathrm{hr}$ managers. Human Resource Management International Digest, 26(5), 18-21. https://doi.org/10.1108 /HRMID-04-2018-0086

Tongco, M. D. C. (2007). Purposive sampling as a tool for informant selection. Ethnobotany Research and Applications, 5, 147-158. https://doi.org/10. 17348/era.5.0.147-158

Tourani, A., \& Rast, S. (2012). Effect of employyees' communication and participation on employees' job satisfaction: An empirical study on airline companies in Iran. A paper presented in $2^{\text {nd }}$ International Conference on Economics, Trade and Development.

Trombetta, J. J., \& Rogers, D. P. (1988). Communication climate, job satisfaction, and organizational commitment: The effects of information adequacy, communication openness, and decision participation. Management Communication Quarterly, 1(4), 494-514. https://doi.org/ $10.1177 \% 2 \mathrm{~F} 0893318988001004003$
Ulrich, D., Younger, J., Brockbank, W., \& Ulrich, M. D. (2013). The state of the hr profession. Human Resource Management, 52(3), 457-471. https://doi.org/DOI:10.1002/hrm.21536

Vorina, A., Simonič, M., \& Vlasova, M. (2017). An analysis of the relationship between job satisfaction and employee engagement. Economic Themes, 55(2), 243-262. https://doi.org/10. 515/ ethemes-2017-0014

Werner, J., M., \& DeSimone, R., L. (2009). Human Resource Development. $5^{\text {th }}$ Edition. Mason, $\mathrm{OH}$ : South-Western.

Wodruffe, C. (1993). What is meant by a competency? Leadership \& Organization Development Journal, 14(1), 29-36. https://doi.org/10.1108/eb053 651

Wong, K. K. K. (2013). Partial least squares structural equation modeling (pls-sem) techniques using smartpls. Marketing Bulletin, 24(1), 1-32. Retrieved from http://marketing-bulletin.massey.ac. nz/V24/MB_V24_T1_Wong.pdf

Yan, X. (2019). Research on corporate public contribution, employee satisfaction and performance in private enterprises. Proceedings of the 4th International Conference on Economy, Judicature, Administration and Humanitarian Projects (JAHP 2019). Part of Advances in Economics, Business and Management Research, 94, 10201024. https://doi. org/10.2991/jahp-19.2019.206 